\title{
Susceptibility and virulence profile of Escherichia coli pathotypes isolated from diarrheic and non-diarrheic calves
}

\section{Perfil de susceptibilidade e virulência de patótipos de Escherichia coli isolados de bezerros diarreicos e não- diarreicos}

\author{
Juliana da Silva Menezes Azola'; Marita Vedovelli Cardozo²*; Bianca de Souza \\ Moreira3; Gabriel Michelutti do Nascimento4; Marcelo Fabiano Gomes Boriollo5; \\ Fernando Antônio de Ávila ${ }^{6}$
}

\section{Highlights}

Multidrug-resistant bacteria were isolated from calves in MG, Brazil.

Pathogenic E. coli were detected in calves.

Salvia officinalis $L$ showed antimicrobial properties against $E$. coli.

\begin{abstract}
Neonatal diarrhea is amongst the most frequent diseases affecting calves, leading to damages in milk production. Although Escherichia coli is a commensal microorganism in the gastrointestinal tract, some pathotypes are known to cause high prevalence of diarrhea and food poisoning. The rapidly increasing resistance of bacteria to antimicrobials leads to the research in new, alternative treatment options. The present study aimed at the detection of $E$. coli pathotypes in newborn diarrheic and non-diarrheic calves, as well as susceptibility tests for antimicrobials and vegetal extracts. Samples were collected from animals located in dairy farms in the state of Minas Gerais, Brazil. The samples were sent for microbiological isolation, genetic identification using PCR and antimicrobial tests. A total of 35 strains from diarrheic animals tested

1 Master's Student at the Agropecuary Microbiology Postgraduate Program, São Paulo State University, School of Agricultural and Veterinary Studies, UNESP/FCAV, Jaboticabal, SP, Brazil. E-mail: julianatutora23@yahoo.com.br

2 Postdoctoral Researcher at the Agropecuary Microbiology Postgraduate Program, UNESP/FCAV, Jaboticabal, SP, Brazil. E-mail: maritavedovelli@gmail.com

${ }^{3}$ Doctoral Student at the Animal Science Postgraduate Program, José do Rosário Vellano University, UNIFENAS, Alfenas, MG, Brazil. E-mail: bsouza.moreira@hotmail.com

${ }^{4}$ Master's Student at the Agropecuary Microbiology Postgraduate Program, UNESP/FCAV, Jaboticabal, SP, Brazil. E-mail: gb.michelutti@gmail.com

${ }^{5}$ Collaborating Researcher, University of Campinas, School of Dentistry, Unicamp/FOP, Piracicaba, SP, Brazil. E-mail: marcelofgb@yahoo.com.br

${ }^{6}$ Full Prof. at the Agropecuary Microbiology Postgraduate Program, UNESP/FCAV, Jaboticabal, SP, Brazil. E-mail: f.avila@fcav.unesp.br

* Author for correspondence
\end{abstract}

Received: May 14, 2020 - Approved: Oct. 04, 2020 
positive for at least one of the virulence genes analyzed: stx1, stx2, eae, bfp and sta. As for the non-diarrheic animals, 9 isolated strains possessed one of or both st $x 1$ and st $x 2$ genes, classifying these non-diarrheic cattle as reservoirs for the STEC pathotype and possible biological vectors of this pathogen. Regarding the susceptibility tests, most isolates displayed resistance to multiple antimicrobial classes. Among the vegetal extracts tested, all isolates tested sensitive to the active ingredient of Salvia officinalis L. (sage). Showcasing an alternative tool to aid in the treatment of pathogenic bacteria.

Key words: Colibacillosis. EPEC. ETEC. Salvia officinalis L. STEC.

\section{Resumo}

A diarreia neonatal é uma das mais recorrentes enfermidades que acometem bezerros, acarretando prejuízos à pecuária leiteira. Escherichia coli é um microrganismo que, embora seja comensal no trato gastro intestinal, pode apresentar alguns patótipos com alta prevalência em causar diarreias e também surtos alimentares. Para o tratamento, a crescente resistência bacteriana a antimicrobianos leva à busca por novas alternativas farmacológicas. O presente trabalho teve como objetivo detectar patótipos de E.coli em bezerros diarreicos e sadios e testar a susceptibilidade dos isolados a extratos vegetais e a antimicrobianos. As coletas foram realizadas em animais pertencentes a fazendas destinadas à produção leiteira no Estado de Minas Gerais, Brasil. As amostras foram submetidas ao isolamento microbiológico, a identificação genética por PCR e a testes antimicrobianos. Foram isoladas 35 estirpes oriundas de animais diarreicos, positivas para pelo menos um gene testado, sendo eles st ${ }_{1^{\prime}}$ st $x_{2^{\prime}}$ eae, bfp e sta. Relacionadas ao isolamento de animais sadios, 9 estirpes foram carreadoras dos genes $s t x_{1}$ stx ${ }_{2}$ ou ambos, caracterizando os bovinos como reservatórios do patótipo STEC e potenciais transmissores desses patógenos. Quanto aos testes de susceptibilidade, encontrou-se isolados resistentes a diferentes classes de antimicrobianos. Entre os extratos testados, houve sensibilidade em todos os isolados frente ao princípio ativo de Salvia officinalis L. (sálvia). Assim, mostra-se como uma alternativa ao combate a patógenos bacterianos.

Palavras-chave: Colibacilose. EPEC. ETEC. Salvia officinalis L. STEC.

\section{Introduction}

Brazil holds an important position globally in milk production. However, some diseases in cattle, such as the neonatal calf diarrhea caused by pathogenic microorganisms, may affect the economy, livestock, and mainly public health due to infections caused by ingestion of milk from contaminated animals. Furthermore, inadequate antimicrobial treatment of infections could lead to the development of drug-resistant strains.

Several studies have reported that pathogenic Escherichia coli is one of the most frequently isolated microorganisms from fecal samples of newborn diarrheic calves. In recent times, several E. coli pathotypes have been identified and classified based on their virulence factors, mechanisms of action, and promotion of disease. Some of the pathotypes include the enterotoxigenic strain (ETEC), shigatoxigenic strain (STEC), and enteropathogenic strain (EPEC). Asymptomatic cattle serve as reservoirs of such pathogenic bacteria and contribute to spreading of the disease by transmitting these agents to the susceptible animals. In addition, pathogenic E. coli are frequently associated with food poisoning in humans, as well as isolated from 
other animals, characterizing this agent as zoonotic.

Several antimicrobial agents are used for the treatment of colibacillosis, an infection caused by pathogenic E. coli, which could lead to drug resistance. Therefore, an antimicrobial susceptibility test is essential for the following: determining the resistance level of bacteria, selecting drugs for use, and avoiding the overuse of the same drugs that would further enhance the drug-resistance of bacteria. However, as the rate at which microorganisms exhibit resistance to multiple antimicrobials is increasing rapidly, new alternative methods are being studied. Currently, the antibacterial activity of vegetal extracts is gaining popularity in the scientific community, thereby opening a vast opportunity for future researches and discoveries.

Our study aims at detecting pathogenic E. coli strains in newborn calves (with and without diarrhea), using microbiological and molecular techniques and by performing susceptibility tests of the isolates against antimicrobials and vegetal extracts.

\section{Materials and Methods}

\section{Analyzed population}

Stool samples were collected from newborn calves ( 1 to 90 days old) in a dairy farm, situated in the southern part of Minas Gerais state in Brazil. The samples were collected between December 2013 and August 2014, during the disease outbreak and before any drug administration. Out of a total of 200 samples, 100 samples each were from diarrheic and non-diarrheic animals housed next to the affected ones. All the animals were manually fed by keepers in an individualized feeding system. All calves were females of Dutch, Jersey, and Gir breeds, as well as crossbreeds obtained from them. Samples were collected directly from the rectum of the animals using sterile swabs and inserted in tubes containing $1 \mathrm{~mL}$ of phosphate-buffered saline (PBS).

\section{Microbiological isolation of E. coli}

In the laboratory, $50 \mu \mathrm{L}$ of individual samples (collected in tubes with PBS) was inoculated on separate HiCrome ${ }^{\mathrm{TM}} \mathrm{E}$. coli agar plates (HiMedia, India) using the pour plate method and spread using the Drigalski spatulas; the plates were incubated at $37^{\circ} \mathrm{C}$ for $24 \mathrm{~h}$. After incubation, the following biochemical assays and inoculation were performed for the identification of E. coli: lactose fermentation, indole production, methyl red and VogesProskauer (MR-VP), citrate usage, and urease production, as well as inoculation in triple sugar iron agar (TSI, Oxoid, England) (Mac Faddin, 1976). From each plate, up to eight colonyforming units were selected to be analyzed for the presence of virulence genes; these isolates were transferred to tubes containing $2 \mathrm{~mL}$ of the brain heart infusion broth $(\mathrm{BHI}$, Himedia, India) and incubated at $37^{\circ} \mathrm{C}$ for 24 h. Following the incubation, aliquots of 750 $\mu \mathrm{L}$ from the cultures were added to $750 \mu \mathrm{L}$ of glycerol and stored in ultra-freezer at $-80^{\circ} \mathrm{C}$ for future analysis.

\section{Molecular detection of virulence factors}

DNA extraction was performed according to the Sambrook and Russel protocol (2001), and the purity of the extracted genetic material was assessed using a 
spectrophotometer, NanoDrop-2000/2000c (Thermo Scientific, USA). For the detection of ETEC, EPEC, and STEC virulence factors, PCR amplifications were carried out using a reaction mixture containing $2 \mu \mathrm{L}$ DNA sample, $45 \mu \mathrm{L}$ PCR mix, $200 \mu \mathrm{M}$ dNTPs $(1 \mu \mathrm{L}), 10$ pmol of each primer $(0.8 \mu \mathrm{L}), 25 \mathrm{mM} \mathrm{MgCl} 2(6 \mu \mathrm{L}), 5 \mathrm{X}$ Green Go Taq ${ }^{\circledast}$ Flexi buffer $(10 \mu \mathrm{L})$, and $5 \mathrm{U}_{\mu \mathrm{L}^{-1}} \mathrm{Go} \mathrm{Taq}^{\circledR}$ Flexi DNA Polymerase (0.25 $\mu \mathrm{L})$; MiliQ water was added to complete the final volume (reagents: Promega Corporation and primers: Invitrogen, USA). Veriti ${ }^{\circledR}$ 96-Well Thermal Cycler (Applied Biosystems, USA) was used for PCR. The cycles consisted of an initial step at $94^{\circ} \mathrm{C}$ for 2 min, followed by 35 cycles, each cycle consisting of the following phases: denaturation at $94^{\circ} \mathrm{C}$ for $30 \mathrm{~s}$, annealing at $50{ }^{\circ} \mathrm{C}$ for $30 \mathrm{~s}\left(56^{\circ} \mathrm{C}\right.$ for the bfp gene), and extension at $72{ }^{\circ} \mathrm{C}$ for $30 \mathrm{~s}$. The final extension step was at $72{ }^{\circ} \mathrm{C}$ for $7 \mathrm{~min}$. Information about the primers is provided in Table 1. The amplified products were analyzed using agarose gel electrophoresis, visualized in UV transilluminator (Major Science, USA), and photographed using document management system (Digidoc ${ }^{\circledR}$ Ltda and Bioagency Ltda, Brazil).

\section{Table 1}

Description of the primers used in PCR reactions

\begin{tabular}{|c|c|c|c|}
\hline Primer & $\begin{array}{c}\text { Nucleotide sequence } \\
\qquad 5^{\prime} \rightarrow 3^{\prime}\end{array}$ & $\begin{array}{l}\text { Length } \\
\text { (base pairs) }\end{array}$ & Reference \\
\hline $\mathrm{Ta}-\mathrm{F}$ & TCCGTGAAACAACATGACGG & \multirow{2}{*}{44} & \multirow{2}{*}{$\begin{array}{l}\text { Salvadori et al. } \\
\text { (2003) }\end{array}$} \\
\hline $\mathrm{Ta}-\mathrm{R}$ & ATAACATCCAGCACAGGCAG & & \\
\hline$T / I-\mathrm{F}$ & AGATATAATGATGGATATGTATC & \multirow{2}{*}{00} & \multirow{2}{*}{$\begin{array}{l}\text { Salvadori et al. } \\
\text { (2003) }\end{array}$} \\
\hline$T / I-\mathrm{R}$ & TAACCCTCGAAATAAATCTC & & \\
\hline$t x_{1}-\mathrm{F}$ & AGAGCGATGTTACGGTTTG & \multirow{2}{*}{88} & \multirow{2}{*}{$\begin{array}{c}\text { China, Pirson, \& Mainil } \\
\text { (1996) }\end{array}$} \\
\hline$t x_{1}-\mathrm{R}$ & TTGCCCCCAGAGTGGATG & & \\
\hline$t x_{2}-F$ & TGGGTTTTTCTTCGGTATC & \multirow{2}{*}{07} & \multirow{2}{*}{$\begin{array}{c}\text { China, Pirson, \& Mainil } \\
\text { (1996) }\end{array}$} \\
\hline$t x_{2}-\mathrm{R}$ & GACATTCTGGTTGACTCTCTT & & \\
\hline$a e-F$ & AGGCTTCGTCACAGTTG & \multirow{2}{*}{70} & \multirow{2}{*}{$\begin{array}{c}\text { China, Pirson, \& Mainil } \\
\text { (1996) }\end{array}$} \\
\hline$a e-\mathrm{R}$ & CCATCGTCACCAGAGGA & & \\
\hline$f p-F$ & GGAAGTCAAATTCATGGGGGTAT & \multirow{2}{*}{00} & \multirow{2}{*}{$\begin{array}{l}\text { Vidal et al. } \\
\text { (2004) }\end{array}$} \\
\hline$f p-\mathrm{R}$ & GGAATCAGACGCAGACTGGTAGT & & \\
\hline
\end{tabular}

\section{Susceptibility tests}

\section{Antimicrobials}

For the antimicrobial susceptibility test the isolated strains were inoculated in tubes containing $3 \mathrm{~mL}$ of $\mathrm{BHI}$ broth and incubated at $37{ }^{\circ} \mathrm{C}$ for $24 \mathrm{~h}$. The suspension was then transferred to tubes containing saline solution $(150 \mathrm{mM} \mathrm{NaCl})$ and standardized at 0.5 using the MacFarland standard as a reference. The suspensions were then seeded in plates containing Müeller-Hinton agar (Himedia, India), using a sterile swab. After $3 \mathrm{~min}$, discs containing antimicrobials were added to the medium (Bauer, Kirby, Sherris, \& Turck, 1966). 
The antimicrobials used were selected based on on frequency of their usage in cattle industry, and they were as follows: ampicillin $(10 \mu \mathrm{g})$, cefalotin $(30 \mu \mathrm{g})$, streptomycin (10 $\mu \mathrm{g})$, gentamicin $(10 \mu \mathrm{g})$, ciprofloxacin $(5 \mu \mathrm{g})$, chloramphenicol $(30 \mu \mathrm{g})$, tetracycline $(30 \mu \mathrm{g})$, nitrofurantoin $(300 \mu \mathrm{g})$, sulfamethoxazoletrimethoprim $(25 \mu \mathrm{g})$, and nalidixic acid (30 $\mu \mathrm{g})$. Thereafter, the zones of inhibition were analyzed; the diameters of the halos were measured and evaluated according to the Clinical and Laboratory Standards Institute [CLSI] (2013) guidelines. A standard strain of $E$. coli (ATCC 25922) was used as a control in this test. To assess the multiple drug resistance factor, the multiple antibiotic resistance (MAR) index was used and was calculated as the ratio of "a" and "b", where "a" is the number of antimicrobials to which the isolate exhibited resistance, and " $b$ " is the total number of antimicrobials tested. A final result greater than 0.2 indicated that the isolate was multidrugresistant (Krumperman, 1983).

For calculation of the minimum inhibitory concentration (MIC), the Epsilometer test (E-test) was used (Biomérieux Ltda), in which plastic strips containing concentration gradients of gentamicin $(10 \mu \mathrm{gg})$ and sulfamethoxazole-trimethoprim $(25 \mu \mathrm{g})$ were placed on top of the inoculum. The isolated strains were prepared according to the previously described antibiogram (CLSI, 2013).

\section{Vegetal extracts}

The hydroalcoholic extracts tested were derived from the following sources: Vernonia polyanthes, sage (Salvia officinalis), garlic (Allium sativum), Achyurocline satureoides, Cupheae carthagenensis, and farmer's friend (Bidens pilosa). These extracts were obtained commercially (Bio Tae Ltda and Asky Ltda, Brazil), stored, and evaporated using a rotary evaporator, model 802 (Fisatom Equipamentos Científicos Ltda, Brazil), following the manufacturer's instructions.

After evaporation, the extracts were transferred to polyethylene flasks and frozen at $-20{ }^{\circ} \mathrm{C}$ as a validation method (Agência Nacional de Vigilância Sanitária [ANVISA], 2010). Following the validation, a lyophilization process was carried out (Christ Lyophilizator mod. Beta 2-16) for seven days, in order to obtain the extracts in a dehydrated powder form. After lyophilization, the flasks were immediately sealed to avoid absorption of moisture and then weighed on an analytical balance for calculation of the obtained mass.

To confirm the antimicrobial activity of the extracts, they were diluted using sterile water to obtain the desired concentrations of 50,100 , and $150 \mathrm{mg} \mathrm{mL}^{-1}$. The maximum threshold was decided after literature research, as the aim was to find the lowest concentration that could exhibit the desired effects, whilst minimizing possible side effects on the host.

The isolates were processed in the same way as previously described, in order to obtain a 0.5 MacFarland standard. Thereafter, the microbial suspensions were seeded on Müeller-Hinton agar plates, and five wells were perforated in each plate using a metallic perforator. The five wells were used as follows: three wells for different concentrations of the extract of interest $\left(50,100\right.$, and $\left.150 \mathrm{mg} \mathrm{mL}^{-1}\right)$, one well for the positive control (chlorhexidine $0.12 \%)$, and the final well for the negative control (sterile water). The extracts were added (200 $\mu \mathrm{L}$ in each well), and the plates were incubated at $37^{\circ} \mathrm{C}$ for $24 \mathrm{~h}$ to facilitate absorption of the 
suspension by the agar. Positive results were characterized by the formation of zones of inhibition (CLSI, 2013).

The MICs for the extracts tested were obtained using the broth microdilution method, following the CLSI guidelines (2013). The final concentrations of each extract to be tested were $25,12.5,6.25,3.125,1.5625,0.78,0.39$, $0.195,0.097,0.05,0.025$, and $0.012 \mathrm{mg} \mathrm{mL}^{-1}$. A 96-well plate was used for the microdilution method; $10 \mu \mathrm{L}$ of the inoculum was added into the wells containing $100 \mu \mathrm{L}$ of Müeller-Hinton broth as well as different concentrations of the extracts to be tested. After addition of the diluted extracts, the plates were incubated at $37^{\circ} \mathrm{C}$ for $24 \mathrm{~h}$, and the results were interpreted by visually analyzing the presence of turbidity compared with that of the positive and negative controls.

The MIC was defined as the lowest concentration capable of inhibiting the bacterial growth, characterized by turbidity in the well (CLSI, 2013). In contrast, the minimum bactericidal concentration (MBC) was determined from wells in which the concentration was greater than the MIC but presented no turbidity after incubation. From these wells, $10 \mu \mathrm{L}$ aliquots were transferred to petri dishes containing HiCrome ${ }^{\mathrm{TM}}$ E. coli agar, which were then incubated at $37^{\circ} \mathrm{C}$ for $24 \mathrm{~h}$. Following the incubation, the lowest extract concentration that inhibited bacterial growth on the plates was observed and defined as the MBC (CLSI, 2013). All extract assays were performed in triplicate.

\section{Results and Discussion}

Out of a total of 100 samples from diarrheic animals, 35 virulent strains were isolated and were found to be positive for at least one of the analyzed genes. Similarly, out of a total of 100 samples from non-diarrheic animals, 9 positive strains were isolated (Tables 2 and 3$)$.

The results of the antimicrobial susceptibility test revealed a high percentage of strains resistant to the antibiotics tested. The MAR index results revealed that out of the 44 analyzed isolates that were resistant to all the antimicrobials tested, 3 isolates (6.7\%) showed an MAR index of 0.3, $8(17.8 \%)$ of 0.4 , $1(2.2 \%)$ of $0.5,3(6.7 \%)$ of $0.6,4(8.9 \%)$ of $0.7,7$ (15.5\%) of 0.9 , and 11 (24.4\%) of 1 . Information regarding the susceptibility profile and the MAR index of the isolates are mentioned in Tables 2 and 3.

For isolates classified as resistant in the antibiogram, an E-test was performed to determine the MIC. For gentamicin $(10 \mu \mathrm{g})$, the following concentrations in the gradient strip were found to have an inhibitory effect: 24, 38,48 , and $64 \mu_{\mathrm{g} \mathrm{mL}}^{-1}$. For sulfamethoxazoletrimethoprim $(25 \mu \mathrm{g})$, all the isolates showed resistance to the drug concentrations present in the gradient strip; this was evident from the absence of an inhibition ellipse.

The results of the vegetal extract susceptibility test revealed that 44 positive isolates from the previous molecular tests showed sensitivity (formation of inhibition zones) only to $S$. officinalis $L$, with inhibition zones ranging from 13 to $22 \mathrm{~mm}$; thus, the isolates displayed qualitative sensitivity to all the concentrations tested.

From the broth microdilution test results, an MIC was established for diarrheic and non-diarrheic animals. Bacterial growth inhibition started at a concentration of 3.125 $\mathrm{mg} \mathrm{mL}^{-1}$ (MIC). For determination of the MBC, 
aliquots from concentrations higher than MIC but with absence of turbidity in the previous test were inoculated on agar plates and incubated. After incubation, all the plates showed bacterial growth for all the concentrations tested.

Diarrhea is one of the main causes of morbidity and mortality in newborn calves around the world, and many studies have reported the presence of pathogenic $E$. coli in cattle (Bonardi et al., 2015; Shahrani, Dehkordi, \& Momtaz, 2014; Moura, Ludovico, Valadares, Gatti, \& Leite, 2012). In our study, a PCR analysis revealed that the isolates were positive to virulence factors related to the $E$. coli pathotypes ETEC, EPEC, and STEC.

\section{Table 2}

\section{Pathogenic and resistance profiles of isolates from diarrheic animals}

\begin{tabular}{|c|c|c|c|c|c|}
\hline Isolate & Sample & Pathotype & $\begin{array}{l}\text { Virulence } \\
\text { factor }\end{array}$ & Resistance & M.A.R.** \\
\hline 1 & $25 \mathrm{C}$ & EPEC & eae & GEN, STR, TCN, AMP, SMX, NIT, CFL. & 0.7 \\
\hline 2 & $25 \mathrm{C}$ & EPEC & eae & GEN, STR, TCN, NAL, CIP, AMP, SMX, NIT, CFL. & 0.9 \\
\hline 3 & $26 \mathrm{C}$ & EPEC & eae & * & 1 \\
\hline 4 & $26 \mathrm{C}$ & EPEC & eae & GEN, STR, TCN, NAL, CIP, AMP, SMX, NIT, CFL. & 0.9 \\
\hline 5 & $28 \mathrm{C}$ & EPEC & eae & * & 1 \\
\hline 6 & $28 \mathrm{C}$ & EPEC & eae & * & 1 \\
\hline 7 & $33 \mathrm{C}$ & EPEC & eae & STR, TCN, AMP, SMX, NIT, CFL. & 0.6 \\
\hline 8 & $33 \mathrm{C}$ & EPEC & eae & GEN, STR, TCN, NAL, CIP, AMP, SMX, NIT, CFL. & 0.9 \\
\hline 9 & $14 \mathrm{C}$ & EPEC & $e a e+b f p$ & TCN, AMP, SMX, NIT, CFL. & 0.4 \\
\hline 10 & $88 \mathrm{C}$ & ETEC & sta & * & 1 \\
\hline 11 & $10 \mathrm{C}$ & STEC & stx1 & STR, TCN, NAL, AMP, CIP, SMX, NIT, CFL. & 0.8 \\
\hline 12 & $22 \mathrm{C}$ & STEC & stx1 & GEN, STR, TCN, AMP, CHL, SMX, NIT, CFL. & 0.8 \\
\hline 13 & $24 \mathrm{C}$ & STEC & stx 1 & * & 1 \\
\hline 14 & $32 \mathrm{C}$ & STEC & stx1 & STR, TCN, NAL, CIP, SMX, CFL. & 0.6 \\
\hline 15 & $43 \mathrm{C}$ & STEC & stx1 & * & 1 \\
\hline 16 & $72 \mathrm{C}$ & STEC & stx2 & STR, TCN, NAL, AMP, CHL, SMX, CFL. & 0.7 \\
\hline 17 & $5 \mathrm{C}$ & STEC & stx2 & STR, TCN, AMP. & 0.3 \\
\hline 18 & $61 \mathrm{C}$ & STEC & stx2 & GEN, STR, TCN, AMP. & 0.3 \\
\hline 19 & $12 \mathrm{C}$ & STEC & $s t \times 1+s t \times 2$ & GEN, STR, TCN, NAL, CHL, AMP, CIP, SMX. & 0.8 \\
\hline 20 & $13 \mathrm{C}$ & STEC & $s t \times 1+s t \times 2$ & STR, TCN, AMP, CHL, SMX, CFL. & 0.6 \\
\hline 21 & $23 \mathrm{C}$ & STEC & $s t \times 1+s t x 2$ & GEN, STR, TCN, NAL, CHL, AMP, SMX, NIT, CFL. & 0.9 \\
\hline 22 & $30 \mathrm{C}$ & STEC & $s t \times 1+s t \times 2$ & GEN, STR, TCN, NAL, AMP, CIP, SMX, NIT, CFL. & 0.9 \\
\hline 23 & $18 \mathrm{C}$ & STEC & $s t \times 1+s t \times 2$ & STR, TCN, AMP, CHL, SMX, NIT, CFL. & 0.7 \\
\hline 24 & $19 \mathrm{C}$ & STEC & $s t \times 1+s t \times 2$ & STR, TCN, NAL, NIT. & 0.4 \\
\hline 25 & $20 \mathrm{C}$ & STEC & $s t \times 1+s t x 2$ & GEN, STR, TCN, AMP, SMX, NIT, CFL. & 0.7 \\
\hline 26 & $34 \mathrm{C}$ & STEC & $s t \times 1+s t \times 2$ & * & 1 \\
\hline
\end{tabular}

continue... 
contuation...

\begin{tabular}{|c|c|c|c|c|c|}
\hline 27 & $35 \mathrm{C}$ & STEC & $s t \times 1+s t \times 2$ & * & 1 \\
\hline 28 & $44 \mathrm{C}$ & STEC & stx1 + eae & GEN, STR, TCN, NAL, AMP, CIP, NIT, CFL. & 0.8 \\
\hline 29 & $56 \mathrm{C}$ & STEC & stx1+eae & STR, TCN, NAL, AMP, CHL, CIP, SMX, CFL. & 0.8 \\
\hline 30 & $57 \mathrm{C}$ & STEC & stx2 + eae & STR, TCN, NAL, CHL, AMP, CIP, SMX, CFL. & 0.8 \\
\hline 31 & $4 \mathrm{C}$ & STEC & stx2 + eae & STR, CFL, AMP, NIT. & 0.4 \\
\hline 32 & $36 \mathrm{C}$ & STEC & $\begin{array}{c}s t x 1+s t x 2 \\
+ \text { eae }\end{array}$ & STR, GEN, TCN, CHL, AMP, SMX, NIT, CFL. & 0.8 \\
\hline 33 & $58 \mathrm{C}$ & STEC & $\begin{array}{l}\text { stx } 1+s t x 2 \\
\quad+e a e\end{array}$ & GEN, STR, TCN, NAL, CHL, AMP, CIP, SMX, CFL. & 0.9 \\
\hline 34 & $60 \mathrm{C}$ & STEC & $\begin{array}{c}s t x 1+s t x 2 \\
+ \text { eae }\end{array}$ & STR, TCN, NAL, CHL, AMP, CIP, SMX, NIT, CHL. & 0.9 \\
\hline 35 & $74 \mathrm{C}$ & STEC & $\begin{array}{l}\text { stx } 1+s t x 2 \\
+ \text { eae }\end{array}$ & * & 1 \\
\hline
\end{tabular}

GEN: gentamicine; STR: streptomycin; TCN: tetracycline; NAL: nalidixic acid; CHL: chloramphenicol;

AMP: ampicillin; CIP: ciprofloxacin; SMX: trimethoprim/sulfamethoxazole; NIT: nitrofurantoin; CFL: cefalotin

* resistance to all antimicrobials tested

** multiple antimicrobial resistance index.

\section{Table 3}

Pathogenic and resistance profiles of isolates from non-diarrheic animals

\begin{tabular}{|c|c|c|c|c|c|}
\hline Isolate & Sample & Pathotype & Virulence factor & Resistance & M.A.R.** \\
\hline 1 & $10 \mathrm{~S}$ & STEC & stx 1 & STR, TCN, CFL & 0.3 \\
\hline 2 & $22 S$ & STEC & stx 1 & GEN, STR, TCN, CFL & 0.4 \\
\hline 3 & $43 \mathrm{~S}$ & STEC & stx 1 & STR, TCN, AMP, CFL & 0.4 \\
\hline 4 & $47 \mathrm{~S}$ & STEC & stx2 & STR, TCN, AMP, CFL & 0.4 \\
\hline 5 & $58 \mathrm{~S}$ & STEC & stx2 & GEN, STR, TCN, CFL & 0.4 \\
\hline 6 & $59 S$ & STEC & $s t \times 1+s t \times 2$ & GEN, STR, TCN, AMP & 0.4 \\
\hline 7 & $63 \mathrm{~S}$ & STEC & $s t \times 1+s t \times 2$ & STR, TCN, AMP & 0.3 \\
\hline 8 & $69 S$ & STEC & $s t x 1+s t x 2$ & * & 1 \\
\hline 9 & $99 \mathrm{~S}$ & STEC & $s t x 1+s t \times 2$ & * & 1 \\
\hline
\end{tabular}

GEN: gentamicine; STR: streptomycin; TCN: tetracycline; AMP: ampicillin; CFL: cefalotin

* resistance to all antimicrobials tested

** multiple antimicrobial resistance index.

In a previous study by Gregory et al. (2014), on verifying the presence of bacterial agents in the stool samples from buffalo calves in the states of São Paulo and Paraná, a high incidence of the presence of $E$. coli was observed in a total of $97.8 \%$ (45 out of 46) samples. After the genetic evaluation of these isolates, two of them were classified as STEC. This method highlighted the importance of genetic identification to confirm virulent 
strains, as these bacteria are naturally present in the microbiome of ruminants and, therefore, frequently found in their feces.

Furthermore, the samples obtained from non-diarrheic animals were found to contain the pathogenic strains. Moura et al. (2012) identified pathogenic bacteria, STEC, in their study, both from diarrheic and nondiarrheic newborn calves. In both the cases, more than $40 \%$ of the isolates were STEC positive. Thus, it is important to analyze both the affected and not affected animals, since asymptomatic animals (mistaken to be healthy) can still transmit pathogenic bacteria to other animals and humans (Koneman, Allen, Janda, Schreckenberger, \& Winn, 2001).

Similar to this study, Moura et al. (2012) also reported isolates positive for the genes stx1, stx2, and eae. Akiyama et al. (2015) found the STEC, ETEC and EPEC pathotypes by detecting the genes stx $1, s t \times 2, s t$, It, and eae. The presence of the eae gene, both in the aforementioned studies and in our study, indicates an important virulence factor that acts as an aggravator of the infection. Furthermore, these pathogens are linked to zoonotic diseases and are a threat to public health. STEC is associated with hemorrhagic colitis and hemolytic-uremic syndrome in humans, whereas EPEC and ETEC are associated with diarrhea in children, as well as gastroenteritis and food poisoning, especially in developing countries. Infections in humans might occur due to the consumption of contaminated food, or the use of contaminated water for irrigation (Bonardi et al., 2015).

$A$ rise in the multidrug-resistant isolates is of concern for researchers. A high resistance rate was noticed on assessment of the MAR indices of isolates. Multiple studies
(Assumpção et al., 2015; Shahrani et al., 2014; Güler, Gündüz, \& Ok, 2008) have identified pathogenic $E$. coli from the stool samples of newborn diarrheic and non-diarrheic calves, displaying elevated antimicrobial resistance. These results and our current work highlights the relevance of studying bacterial multidrug resistance and ways to combat it.

As an alternative treatment, development of natural substances (vegetal extracts) has been exploited in the last few decades, to promote animal and human welfare. This research area is driven by the rising number of microbes resistant to antimicrobials and the incentives by authorities to find alternative methods of treatment (Golestani, Rad, Bassami, \& Afkhami-Goli, 2015). In Brazil, around $80 \%$ of the population uses natural products, especially medicinal herbs, as primary therapeutic resources (Di Stasi, 1996).

The antibacterial properties of $S$. officinalis $L$ were observed in this study. Scientific reports on this plant are mostly aimed at medicines for humans, due to its known antioxidant and anti-inflammatory capabilities. Therefore, studies using this plant aimed at the animal field are all relevant, considering the existence of concerning zoonotic diseases as already mentioned.

Antibacterial activity of essential oils extracted from medicinal herbs was evaluated in $E$. coli strains; $S$. officinalis $L$ displayed superior inhibitory action ( $96 \%$ efficiency) as compared to the other substances (Pereira, Sumita, Furlan, Jorge, \& Ueno, 2004). In Greece, the essential oil from sage was tested against clinical multidrug-resistant $E$. coli isolates, and an MIC of $125 \mathrm{mg} \mathrm{mL}^{-1}$ was obtained (Fournomiti et al., 2015). In another similar study, the inhibitory action of the essential oil 
from sage plant was verified against $E$. coli (ATCC 25922) and two clinical E. coli isolates; its efficiency was supported by the scarce growth of microorganisms in the plates (Lixandru et al., 2010). In a study conducted by Bozin, Mimica-Dukic, Samojlik and Jovin (2007), the antibacterial activity of sage extract was demonstrated against E. coli, Salmonella Typhi, Salmonella Enteritidis, and Shigella sonei. Several studies are using sage plant and different extraction methods for the obtention of the essential oil, displaying a variation in the amount of chemical compounds obtained from different extraction protocols.

During fractionation of the ethanolic extract of $S$. officinalis $L$, the most active antibacterial compound was isolated, and by using chemical data, it was classified as a diterpene,asecondarymetaboliteoftheterpene class (Climati et al., 2013). Synergistic effects of the extracts of $S$. officinalis $L$ and antibiotics such as amoxicillin and chloramphenicol have also been studied; in the presence of the extract, the MIC of the antibiotics reduced 2 to 10 fold (Stefanović, Stanojević, \& Comić, 2012). In another study, an extract obtained from the leaves of sage displayed antimicrobial activity against vancomycin-resistant enterococci, Streptococcus pneumoniae, and methicillinresistant Staphylococcus aureus (MRSA), and after chemical isolation, the compound responsible for the antibacterial activity was identified to be oleanolic acid, a triterpene (Horiuchi et al., 2007).

The results of $\mathrm{MBC}$ analysis in our study demonstrated that bacteria showed growth for every concentration that was tested. This result indicated a potential bacteriostatic action of the sage extract, which may have exerted sublethal stress on the agents. It is worth noting that the results vary between different studies, according to the extraction method used to obtain the substances and the concentrations tested; thus, every result contributes to the scientific knowledge of this qualitative analysis.

\section{Conclusions}

Asymptomatic animals can be carriers of virulent bacteria and, therefore, may transmit those pathogens to other animals and humans. This highlights the importance of proper management of livestock as well as meeting hygiene and sanitation standards while handling them, in order to avoid potential threat to public health. The high prevalence of multidrug-resistant bacteria, even in nondiarrheic animals, highlights the indiscriminate use of these drugs and the need to reduce this practice. In addition, the vegetal extract of $S$. officinalis $L$ showed bactericidal action in vitro and proved to be a novel, potential agent in the treatment against pathogens. We believe that further research on the effects of these compounds in vivo is crucial for the understanding and development of new ways of treatment against pathogens in animals and humans alike.

\section{Acknowledgements}

The authors would like to thank CAPES - Coordination for the Improvement of Higher Education Personnel for the financial support.

\section{References}

Agência Nacional de Vigilância Sanitária (2010). Farmacopeia brasileira (5a ed., rev. 2). Brasília, DF: ANVISA. 
Akiyama, Y., Saito, E., Futai, H., Ogita, K., Sakae, H., Fukunaga, M., \& Mimura, M. (2015). Comprehensive study of pathogenic genes distributed in Escherichia coli isolated from cattle. Food Hygiene and Safety Science, 56(3), 118-122. doi: 10.3358/shokueishi.56.118

Assumpção, G. L. H., Cardozo, M. V., Beraldo, L. G., Maluta, R. P., Silva, J. T., Avila, F. A., \& Rigobelo, E. C. (2015). Antimicrobials resistance patterns and the presence of stx 1 , stx 2 and eae in Escherichia coli. Revista Brasileira de Saúde e Produção Animal, 16(2), 308-316. doi: 10.1590/ S1519-9940201500020 0006

Bauer, A. W., Kirby, W. M. M., Sherris, J. C., \& Turck, M. (1966). Antibiotic susceptibility testing by a standardized single disk method. American Journal of Clinical Pathology, 45(4), 493-496.

Bonardi, S., Alpigiani, I., Tozzoli, R., Vismarra, A., Zecca, V., Greppi, C., \& Brindani, F. (2015). Shiga toxin-producing Escherichia coli 0157, 026 and 0111 in cattle faeces and hides in Italy. Veterinary Record Open, 2(1), 1-9. doi: 10.1136/vetreco-2014-000061

Bozin, B., Mimica-Dukic, N., Samojlik, I., \& Jovin, E. (2007). Antimicrobial and antioxidant properties of rosemary and sage (Rosmarinus officinalis $L$. and Salvia officinalis L., Lamiaceae) essential oils. Journal of Agricultural and Food Chemistry, 55(19), 7879-7885. doi: 10. 1021/jf0715323

China, B., Pirson, V., \& Mainil, J. (1996). Typing of bovine attaching and effacing Escherichia coli by multiplex in vitro amplification of virulence-associated genes. Applied and Environmental Microbiology, 62(9), 34623465.
Climati, E., Mastrogiovanni, F., Valeri, M., Salvini, L., Bonechi, C., Mamadalieva, N. Z., \& Tiezzi, A. (2013). Methyl carnosate, an antibacterial diterpene isolated from Salvia officinalis leaves. Natural Product Communications, 8(4), 429-430.

Clinical and Laboratory Standard Institute (2013). Performance standards for antimicrobial disk susceptibility tests, CLSI Document M100-S23, twenty-third informational supplement (33th ed., rev. 1). Wayne, PA: CLSI.

Di Stasi, L. C. (1996). Plantas medicinais, arte e ciência: um guia prático para estudo interdisciplinar. São Paulo, SP: UNESP.

Fournomiti, M., Kimbaris, A., Mantzourani, I., Plessas, S., Theodoridou I., Papaemmanouil, V., \& Alexopoulos, A. (2015). Antimicrobial activity of essential oils of cultivated oregano (Origanum vulgare), sage (Salvia officinalis), and thyme (Thymus vulgaris) against clinical isolates of Escherichia coli, Klebsiella oxytoca, and Klebsiella pneumoniae. Microbial Ecology in Health and Disease, 26(1), 1-7. doi: 10.3402/mehd.v26.23289

Golestani, M. R., Rad, M., Bassami, M., \& Afkhami-Goli, A. (2015). Analysis and evaluation of antibacterial effects of new herbal formulas, AP-001 and AP-002, against Escherichia coli O157:H7. Life Sciences, 135(1), 22-26. doi: 10.1016/j. Ifs.2015.05.007

Gregory, L., Rossi, R. S., Mendes, J. P. G., Neuwirt, N., Marques, E. C., Melville, P. A., \& Monteiro, B. M. (2014). Ocorrência dos principais agentes bacterianos e parasitários em fezes diarreicas de bezerros búfalos nos estados de São Paulo e Paraná. Arquivos do Instituto Biológico, 81(2), 180-185. doi: 10. $1590 / 1808-1657001122012$ 
Güler, L., Gündüz, K., \& Ok, Ü. (2008). Virulence factors and antimicrobial susceptibility of Escherichia coli isolated from calves in Turkey. Zoonoses and Public Health, 55(5), 249-257. doi: 10.1111/j.1863-23 78.2008.01121.x

Horiuchi, K., Shiota, S., Hatano, T., Yoshida, T., Kuroda, T., \& Tsuchiya, T. (2007). Antimicrobial activity of oleanolic acid from Salvia officinalis and related compounds on vancomycin-resistant enterococci (VRE). Biological and Pharmaceutical Bulletin, 30(6), 1147-1149. doi: 10.1248/ bpb.30.1147

Koneman, E. W., Allen, S. D., Janda, W. M., Schreckenberger, P. C., \& Winn, W. C. Jr. (2001). Diagnóstico microbiológico, (5th ed.). Rio de Janeiro, RJ: Medsi.

Krumperman, P. H. (1983). Multiple antibiotic resistence indexing of Escherichia coli to identify high risk sources of fecal contamination of foods. Applied Environment Microbiology, 46(1), 165-170.

Lixandru, B. E., Drãcea, N. O., Dragomirescu, C. C., Drãgulescu, E. C., Coldea, I. L., Anton, L., \& Coditã, I. (2010). Antimicrobial activity of plant essential oils against bacterial and fungal species involved in food poisoning and/or food decay. Roumanian Archives of Microbiology and Immunology, 69(4), 224-230.

Mac Faddin, J. F. (1976). Biochemical tests for identification of medical bacteria. Baltimore, MD: Williams \& Wilkins.

Moura, C., Ludovico, M., Valadares, G. F., Gatti, M. S. V., \& Leite, D. S. (2012). Detection of virulence genes in Escherichia coli strains isolated from diarrheic and healthy feces of dairy calves in Brazil. Arquivos do Instituto Biológico, 79(2), 273-276. doi: 10.1590/S1808-16572012000200016

Pereira, R. S., Sumita, T. C., Furlan, M. R., Jorge, A. O. C., \& Ueno, M. (2004). Antibacterial activity of essential oils on microorganisms isolated from urinary tract infection. Revista de Saúde Pública, 38(2), 326-328. doi: 10.1590/S0034-89 102004000200025

Salvadori, M. R., Valadares, G. F., Leite, D. S., Blanco, J., \& Yano, T. (2003). Virulence factors of Escherichia coli isolated from calves with diarrhea in Brazil. Brazilian JournalofMicrobiology,34(3), 230-235. doi: 10.1590/S1517-83822003000300009

Sambrook, J., \& Russell, D. W. (2001). Molecular cloning: a laboratory manual (3a ed.). London: CSHL Press.

Shahrani, M., Dehkordi, FS., \& Momtaz, H. (2014). Characterization of Escherichia coli virulence genes, pathotypes and antibiotic resistance properties in diarrheic calves in Iran. Biological Research, 47(1), 28. doi: 10.1186/0717-6287-47-28

Stefanović, O. D., Stanojević, D. D., \& Comić, L. R. (2012). Synergistic antibacterial activity of Salvia officinalis and Cichorium intybus extracts and antibiotics. Acta Poloniae Pharmaceutica, 69(3), 457-463.

Vidal, R., Vidal, M., Lagos, R., Levine, M., \& Prado, V. (2004). Multiplex PCR for diagnosis of enteric infections associated with diarrheagenic Escherichia coli. Journal of Clinical Microbiology, 42(4), 1787-1789. doi: 10.1128/jcm.42.4.1787-1789.2004 